Article

\title{
Low-Level Organic Solvents Improve Multienzyme Whole-Cell Catalytic Synthesis of Myricetin-7-O-Glucuronide
}

\author{
Yan Yang ${ }^{1,2}$, Min-Zhi Liu ${ }^{2}$, Yun-Song Cao ${ }^{2}$, Chang-Kun $\mathrm{Li}^{3}$ and Wei Wang ${ }^{1,2, *}$ \\ 1 State Key Laboratory of Bioactive Substance and Function of Natural Medicines, Institute of Materia Medica, \\ Chinese Academy of Medical Sciences \& Peking Union Medical College, Beijing 100050, China; \\ yangyan@imm.ac.cn \\ 2 Key Laboratory of Biosynthesis of Natural Products of National Health Commission of the People's Republic \\ of China, Institute of Materia Medica, Chinese Academy of Medical Sciences \& Peking Union Medical \\ College, Beijing 100050, China; lmzluoxue@imm.ac.cn (M.-Z.L.); caoyunsong@imm.ac.cn (Y.-S.C.) \\ 3 Beijing Branch, Shimadzu (China) Co. Ltd., Beijing 100020, China; fxlck@shimadzu.com.cn \\ * Correspondence: wwang@imm.ac.cn; Tel.: +86-10-631-65196
}

Received: 18 October 2019; Accepted: 15 November 2019; Published: 18 November 2019

\begin{abstract}
Multienzyme whole-cell biocatalysts are preferred in industrial applications, and two major concerns regarding the use of these biocatalysts, cell viability and cell membrane integrity, must be addressed. In this work, the transformation of myricetin to myricetin-7-O-glucuronide catalyzed by an engineered Escherichia coli strain was taken as the model reaction to examine the impacts of low-level organic solvents on whole-cell biocatalysis. Low-level organic solvents $(2 \%, v / v)$ showed a significant increase (roughly 13-fold) in myricetin-7-O-glucuronide yields. No obvious compromises of cellular viability and integrity were observed by a flow cytometry assay or in the determination of extracellular protein leakage, suggesting the addition of low-level organic solvents accommodates whole E. coli cells. Furthermore, a scaled-up reaction was conducted to test the capability and efficiency of whole-cell catalysis in the presence of organic solvents. This study presents a promising and simple means to enhance the productivity of multienzyme whole-cell catalysis without losing the barrier functions of the cell membrane.
\end{abstract}

Keywords: engineered Escherichia coli; flavonoid glucuronides; multienzyme whole-cell biocatalyst; organic solvents

\section{Introduction}

Multistep whole-cell catalysis is becoming a fast-developing area in the field of biocatalysis [1,2]. A single, tailored, whole-cell biocatalyst containing all of the required enzymes not only offers a high degree of selectivity, including regio-, stereo-and enantio-selectivity [3,4], but is also superior to in vitro enzyme biotransformation, as it circumvents cell lysis, enzyme purification, and the addition of external cofactors (e.g., $\mathrm{NAD}(\mathrm{P}) \mathrm{H}$ and ATP). In addition to these capacities, microbial cells provide a protective environment for enzymes, preventing conformational changes from occurring in the protein structure in non-conventional media or under harsh reaction conditions $[1,5]$.

Whole-cell biocatalysts have been widely used as an excellent alternative means to directly convert different substrates into fine chemicals [2,6], but they are generally less efficient than reactions catalyzed by isolated enzymes by a factor of one or two orders of magnitude $[7,8]$. The most prominent limitations are unimpeded transport of the substrate into and the final product out of the cell [8]. Since hydrophobic substrates can enter cells through passive diffusion [9], the solubility of substrates is generally considered a limiting factor, and the permeability of the cell membrane as a 
mass transfer barrier is a most common concern for whole-cell bioprocesses. Although many chemical (e.g., by adding detergents or solvents) and physical (e.g., temperature shock) treatments are used to improve the permeability of cell membranes, they may compromise cell integrity, spur the leakage of cellular components (e.g., diffusional loss of $\mathrm{NAD}(\mathrm{P}) \mathrm{H})$, and affect downstream processes [10]. Given the attractive advantages of conventional water-miscible organic solvents, including their simple management, high solubility for various organic substances, and capacities to improve the enantio-selectivity and activity of biocatalysts [11,12], organic solvents have been used as "cosolvents" and "permeability enhancers" to stimulate substrate transfer across cells [7,10], but the choice and amount of added organic solvent are highly empirical and generally undesirable for large-scale applications [13]. In most single-enzyme whole-cell catalytic processes, dimethyl sulfoxide (DMSO) and methanol $(\mathrm{MeOH})$ are commonly used as solubility enhancers to promote the biosynthesis of glycosides and hydrophobic compounds [14,15]. The use of a recombinant single enzyme overexpressed in Escherichia coli is employed as a whole-cell biocatalyst treated with $60 \%$ acetone $(v / v)[16]$ or $10 \%$ ethanol (EtOH) [11] to enhance the permeabilization of cell membranes and, further, to promote high yields of L-phenylalanine and L-menthol.

Although the above studies have demonstrated that organic solvents are effective in enhancing the yields of whole-cell reactions by affecting substrate solubility or cellular permeability, a widespread means to balance the contradiction between reducing barrier-like actions and maintaining the integrity of the cell membrane remain elusive. In addition, the presence of an intact cell is required for whole-cell catalysis, and especially for multienzyme whole-cell reactions coupled with the (re)generation of cofactors and energy molecules. While adaptation of bacterial cells to the organic solvent is an important issue to be addressed $[17,18]$, little attention has been paid to the lesser negative effects on cell survival and membrane integrity resulting from the use of low-level organic solvents that can affect bioconversion efficiency. Indeed, biocatalytic systems, especially whole-cell ones, can be very sensitive to organic solvents.

In this study, an engineered E. coli BPGUT [19] performing the multienzyme cascade biosynthesis of a uridine diphosphate (UDP) sugar donor, which requires the (re)generation of redox $(\mathrm{NAD}(\mathrm{P}) \mathrm{H})$ and energy ATP, was used as a multienzyme whole-cell model biocatalyst to test the effects of organic solvents on the conversion of myricetin into myricetin-7-O-glucuronide (M7GA) (Scheme 1). Myricetin is a natural plant-derived flavonoid that has been well recognized for its nutraceutical value, but which exhibits limited aqueous solubility [20]. M7GA, a structural analogue of scutellarein-7-O-glucuronide [21], exhibits the potential capacity to treat cardio-cerebral vascular diseases. Herein, we focused on the influence of different organic solvents on the one-pot whole-cell reaction. The effects of the addition of low-level water-miscible organic solvents on solubility and bioconversion rates and on microbial cellular viability and membrane integrity were investigated. Additionally, the whole-cell reaction for producing M7GA with the use of optimal organic solvent was scaled up.

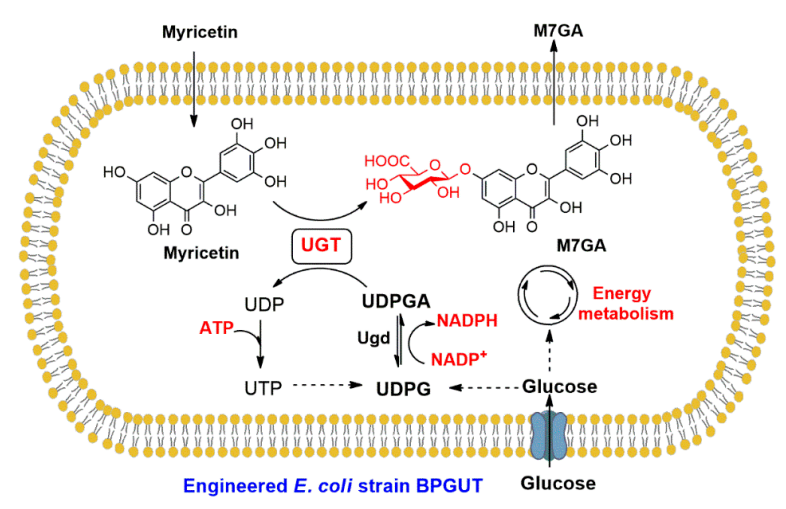

Scheme 1. Production of myricetin-7-O-glucuronide (M7GA) from myricetin with engineered Escherichia coli BPGUT cells used as the whole-cell biocatalyst. 


\section{Results and Discussion}

\subsection{Effects of the Organic Solvents on Bioconversion}

As many flavonoid aglycones have been suggested to be able to move into cells through passive diffusion [22-24], a high concentration gradient of flavonoid aglycones in a metabolic cell aqueous system may allow for a higher level of cross-membrane uptake. The screening test involving the addition of $2 \%-10 \%$ organic solvents to the reaction system (Figure $1 \mathrm{~A}$ and Table S1) showed that all of the organic solvents tested (except for 10\% acetone and 10\% EtOH) triggered higher degrees of yield, with the highest value observed following the addition of $2 \%$ acetone, $2 \% \mathrm{EtOH}$ and $2 \% \mathrm{MeOH}$ (over 13-fold increase). M7GA yields underwent a steep decline when acetone and EtOH concentrations reached $10 \%$, exhibiting $10 \%-27 \%$ decreases relative to the control. The conversion rate underwent an approximate 9-fold increase relative to the control when the $N, N$-dimethylformamide (DMF) and DMSO concentrations were $2 \%$, and the product yield decreased slowly as the content of DMF and DMSO sequentially increased.

The solubilities of myricetin and M7GA coupled with working concentrations of organic solvent were evaluated. As shown in Figure 1B and Table S1, the addition of organic solvents can induce minor improvements (ranging from $16 \%$ to $200 \%$ ) in the solubility of myricetin in the presence of DMF and DMSO $(2 \%, v / v)$, of acetone and $\mathrm{EtOH}(2 \%$ or $5 \%, v / v)$ or of $\mathrm{MeOH}$ (below $10 \%, v / v)$ relative to the control. However, the solubility of myricetin with acetone or DMF or DMSO $(10 \%, v / v)$ was dramatically stimulated by approximately 22 - to 48 -fold relative to the one obtained from the control. In contrast to the substrate myricetin, the product M7GA showed good solubility in modified M9 medium and those with low-level organic solvents (Figure 1C and Table S1). Almost 68\% of M7GA dissolved in modified M9 medium, with only minor differences in the solubility of M7GA (less than $31 \%$ ) among the tested solutions, which indicated that the inherent hydrophilic property of M7GA rather than the presence of organic solvent improved the solubility or the transport pace of the product.

A step-down relationship was found between yields and organic solvent content levels in the reaction system, with an optimal value attained when the volume of organic solvents was only $2 \%$ (Figure 1A). A step-up relationship was found between solubility levels and organic solvent content, with an optimal value obtained when the volumes of certain organic solvents reached $10 \%$ $(v / v)$ (Figure 1B). Low concentrations of organic solvents exhibited accelerating potential during the biocatalytic conversion of myricetin into M7GA, with a slight increase in solubility. Moreover, when plotting production yields against the solubility of myricetin for the respective M9 solution with organic solvents, an obvious decrease in yields accompanied by an increase in myricetin solubility was found (Figure S1), possibly related to interactions between the cells and added organic solvents, which may have affected the surface tension, fluidity, permeability, or integrity of cellular membranes or further caused the leakage of intracellular small molecules (e.g., UDP-sugars, NAD(P)H, or ATP). DMSO can increase membrane fluidity, reduce membrane thickness, form transient water pores, or destroy the membrane structure with increases in concentrations $[13,25]$. Short-chain alkanols $(\mathrm{MeOH}$ and $\mathrm{EtOH}$ ) can partition into cell membranes and reduce surface tension. As concentrations increase, the membrane becomes overly fluid, which further damages its integrity [26-28]. Thus, a low concentration of organic solvent reduces mass-transfer resistance from the membranes of whole cells, and a high concentration of organic solvent damages the membrane structure and integrity. Certainly, low or high concentrations of organic solvent should be correlated with cell density $\left(\mathrm{OD}_{600}=6.0,12 \mathrm{~g}\right.$ cells L $^{-1}$ in this study). 

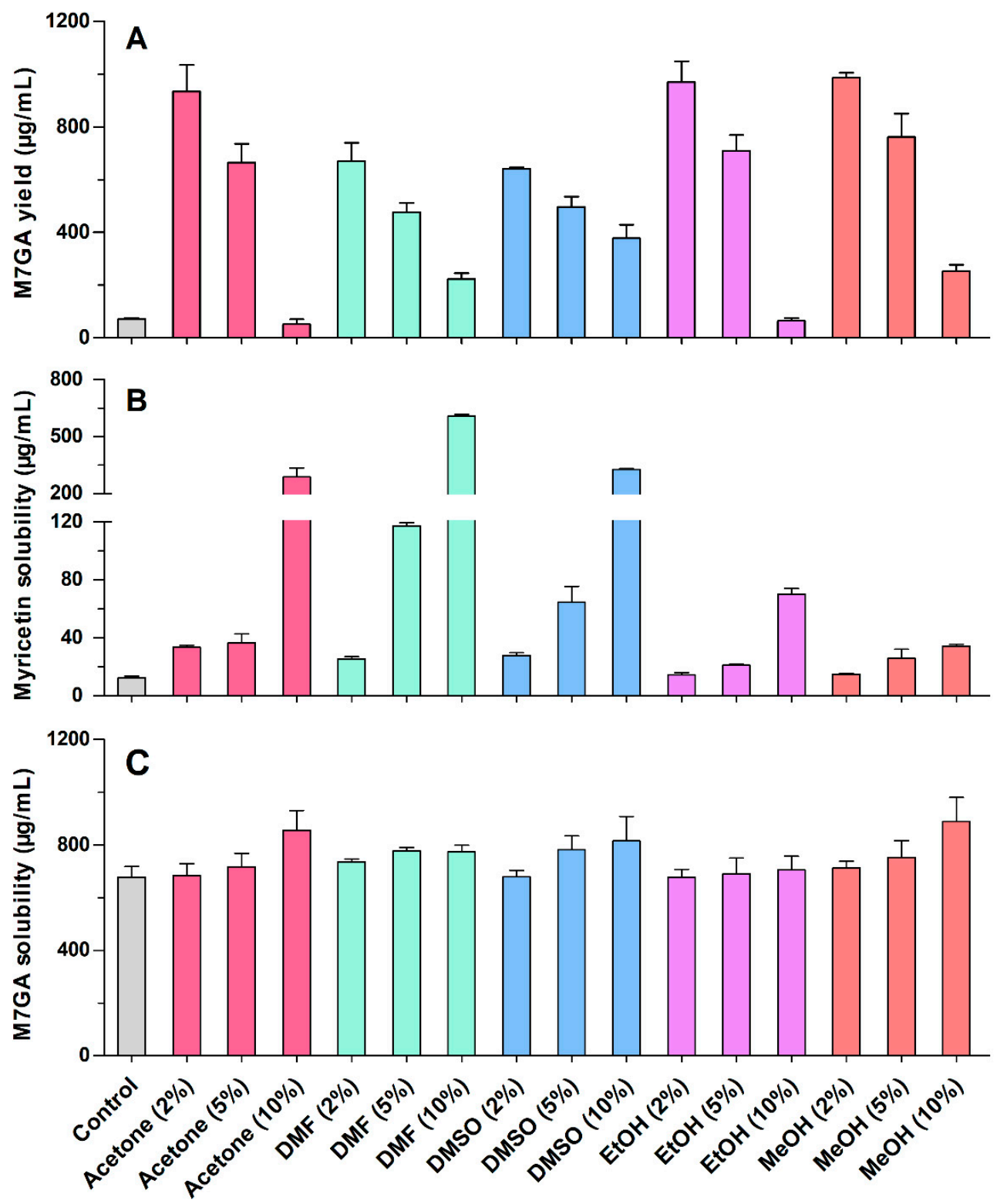

Figure 1. Effects of different organic solvents on the whole-cell reaction and the substrate and product solubilities. (A) Bioconversion of myricetin to myricetin-7-O-glucuronide (M7GA) catalyzed by E. coli BPGUT cells in the presence of organic solvents; (B) The solubility of myricetin and (C) the solubility of M7GA obtained in the modified M9 medium containing different concentrations of organic solvents.

\subsection{Cell Viability and Its Impacts on Bioconversion}

To clarify the effects of the addition of organic solvents on the catalytic activity of E. coli BPGUT in converting myricetin into M7GA, we assumed that these additives may primarily affect bioconversion through their interactions with cell membranes. Whether cell membranes are damaged or not can be determined from cell viability. In this study, the viability of the treated cells was assessed through the flow cytometry (FCM) test, as dead cells with damaged cytoplasmic membranes exhibit red fluorescence (due to propidium iodide (PI) staining), and live cells with intact membranes appear green (due to SYTO9 staining).

As can be observed from the FCM micrographs (Figure 2 and Table S2), the addition of $20 \%$ acetone and $20 \% \mathrm{EtOH}$ seriously disrupted cell membranes, leading to cell death; the disruptions became much more severe when cells suffered from $20 \%$ concentrations of acetone and EtOH than from $2 \%$ concentrations, reflecting a result distinct from that observed for cells treated with DMSO 
and DMF (Figure 2). Interestingly, although the distinction in production yield was obvious when different organic solvents $(2 \%-10 \%)$ were added, the FCM test for cell viability did not show obvious differences (Figure 2). However, when the cells were treated with $20 \%$ acetone and $20 \% \mathrm{EtOH}$, the damage was the most severe, and coincidently, the yields of M7GA were the lowest when $10 \%$ acetone and $10 \% \mathrm{EtOH}$ were used.
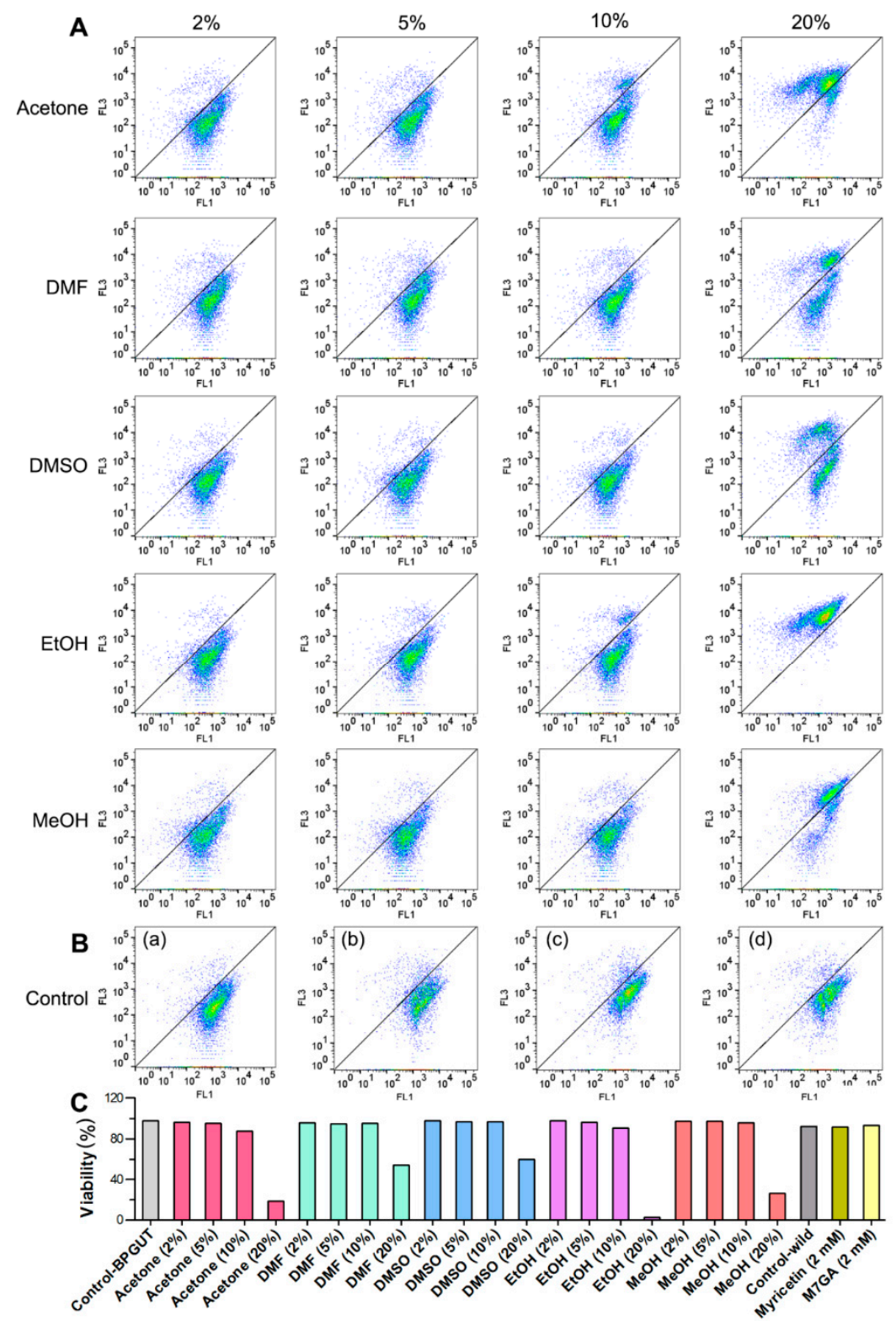

Figure 2. Viability of E. coli BPUGT cells or wild-type cells after being treated for $6 \mathrm{~h}$ at $30{ }^{\circ} \mathrm{C}$ in a modified M9 solution containing 2\% (v/v), 5\% (v/v), 10\% (v/v), and 20\% (v/v) of organic solvents, or $2 \mathrm{mM}$ of myricetin and M7GA, respectively. (A) Flow cytometry (FCM) images of organic solvent-treated $E$. coli BPUGT cells; (B) FCM images of untreated E. coli BPUGT cells (a), untreated E. coli wild type cells (b), myricetin-treated E. coli wild type cells (c), and M7GA-treated E. coli wild type cells (d); (C) The cell viability as determined by FCM.

Cell protein leakage was observed after the removal of the treated cells, which serves as another indication of damage to the cell membrane on one hand and reflects the leakage of intracellular small molecules on the other. The levels of protein leakage increased with the increase of organic solvents, especially for acetone and EtOH (Figure 3 and Table S3). The 2\%-10\% organic solvents (DMF and 
DMSO) only spurred a less than twofold increase with respect to the control reaction system, which might be due to the E. coli surface protein. Extracellular protein leakage resulted in a sharp increase when the cells were exposed to acetone (20\%) and $\mathrm{EtOH}(20 \%)$ - containing aqueous solution. This finding was in accordance with that of the FCM tests showing a decrease in the viability of the E. coli cells. These results suggest that the reduced barrier function of cell membranes accompanied by an increase in organic solvents can result in the further leakage of intracellular components essential to multienzyme whole-cell biocatalysts.

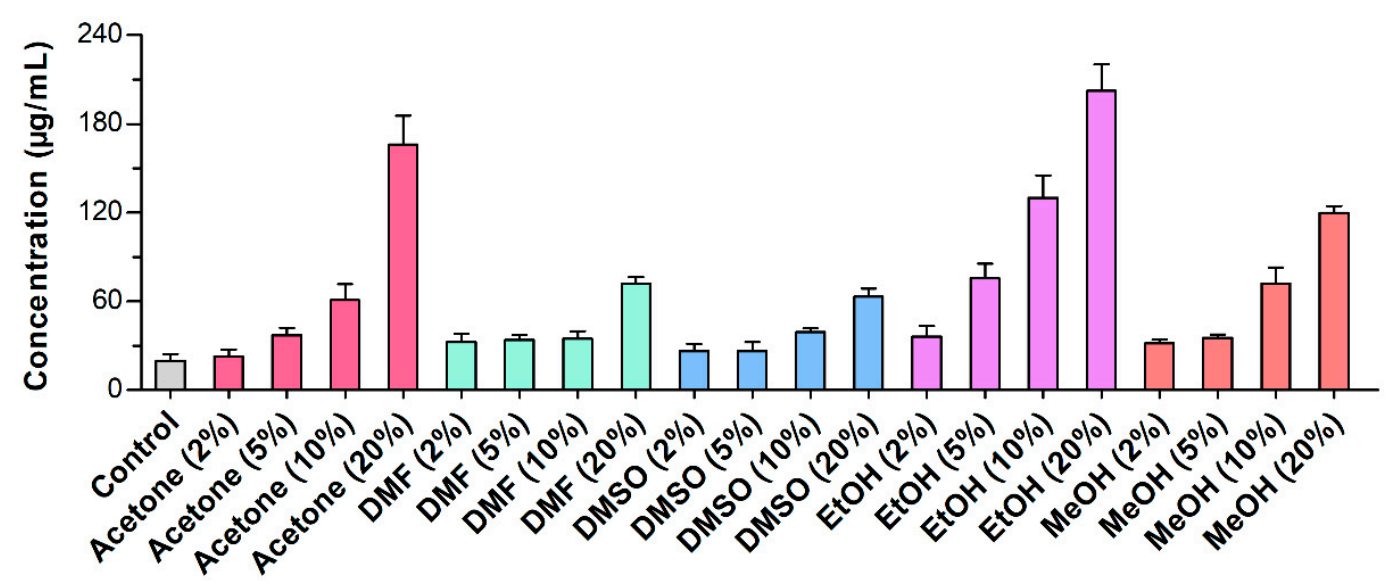

Figure 3. Concentrations of proteins released from E. coli BPGUT cells after the cells were exposed to $2 \%$ $(v / v), 5 \%(v / v), 10 \%(v / v)$ and $20 \%(v / v)$ of acetone, DMF, DMSO, EtOH, and MeOH for $6 \mathrm{~h}$, respectively.

Therefore, the above experiments demonstrate that organic solvents (for the type and concentration domains of organic solvents explored in this work) supported mild interactions with cells, especially in regard to DMSO. The minor improvement in solubility in the presence of low-level organic solvent $(2 \%)$ led to an outstanding increase in yield, and no obvious compromises to cellular viability or integrity were observed from the FCM and protein leakage assay. It is reasonable to speculate that low-level organic solvents probably affected the membrane structure (including fluidity, tension, thickness, permeability, or water pore formation, and so on), which may be referred to as "micro-permeabilization", and the tiny change improved the transport pace of the myricetin. In contrast, the major improvement in solubility in the presence of $10 \%$ of organic solvent led to a major decrease in yield and no prominent compromises to cellular viability or integrity. The explanation for this finding might be the toxicity of organic solvents in the whole-cell reaction system.

\subsection{Scaled-Up Synthesis of M7GA in a Fermenter System}

To further evaluate the industrial potential of the whole-cell strategies, the one-pot bioconversion system was further scaled up to $1 \mathrm{~L}$ in a 3-L fermenter, in which some factors involved in the growth of E. coli, such as $\mathrm{pH}$ and dissolved oxygen, could be controlled. Based on the effects of organic solvents on cell integrity, viability, and stability, DMSO was selected as the co-solvent. A kinetic analysis of M7GA production over time is shown in Figure 4. The M7GA production dramatically increased within $12 \mathrm{~h}$, and the production then incrementally leveled off over time. Finally, approximately $1322 \pm 106 \mathrm{mg} / \mathrm{L}$ (roughly $2.7 \mathrm{mM}$ ) M7GA was produced after $48 \mathrm{~h}$, and a $67 \%$ conversion yield was achieved. 


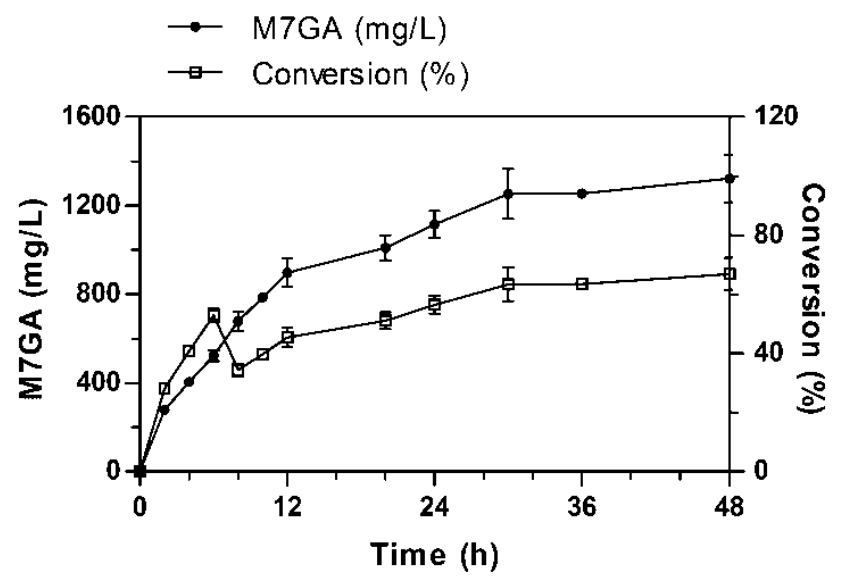

Figure 4. Time course for the production and conversion of myricetin-7-O-glucuronide (M7GA) obtained in a 3-L fermenter system containing $1 \mathrm{~L}$ of whole-cell catalyst. Two volumes of $20 \mathrm{~mL}$ myricetin stock solution (100 mM, dissolved in DMSO) was supplied in the reaction system at $0 \mathrm{~h}$ and $6 \mathrm{~h}$, respectively.

\section{Materials and Methods}

\subsection{Materials}

Myricetin and M7GA were purchased from BioBioPha (Kunming, Yunnan, China). Organic solvents, acetone, DMF, DMSO, EtOH, $\mathrm{MeOH}$, and all other reagents of analytical grade were purchased from local manufacturers (Beijing Chemical Factory, Beijing, China). The LIVE/DEAD BacLight Bacterial Viability Kit (\# L7012), including solutions of $3.34 \mathrm{mM}$ SYTO9 dye and $20 \mathrm{mM}$ propidium iodide (PI) (both dissolved in DMSO), was purchased from Thermo Fisher Scientific (Waltham, MA, USA).

Transformed E. coli cells were grown on Luria-Bertani (LB) medium supplemented with antibiotics (100 mg/L ampicillin, $50 \mathrm{mg} / \mathrm{L}$ kanamycin and $25 \mathrm{mg} / \mathrm{L}$ chloramphenicol). The standard reaction system used for all shake-flask or fermenter production studies consisted of a modified M9 medium ( $\mathrm{pH}$ 7.0, $\mathrm{Na}_{2} \mathrm{HPO}_{4} 6.8 \mathrm{~g} / \mathrm{L} ; \mathrm{KH}_{2} \mathrm{PO}_{4} 2.7 \mathrm{~g} / \mathrm{L} ; \mathrm{NaCl} 0.5 \mathrm{~g} / \mathrm{L} ; \mathrm{NH}_{4} \mathrm{Cl} 1.0 \mathrm{~g} / \mathrm{L} ; \mathrm{MgSO}_{4} 0.24 \mathrm{~g} / \mathrm{L} ; \mathrm{CaCl}_{2} 0.01 \mathrm{~g} / \mathrm{L}$ ) supplemented with glucose $(10 \mathrm{~g} / \mathrm{L})$.

\subsection{Preparation of a Certain Concentration of Organic Solvent}

Myricetin was dissolved in the organic solvents such as acetone, DMF, DMSO, EtOH, and $\mathrm{MeOH}$ to form specific concentrations of myricetin stock solutions $(100 \mathrm{mM}, 40 \mathrm{mM}$, and $20 \mathrm{mM})$. Certain volumes of liquid solvents (acetone, DMF, DMSO, $\mathrm{EtOH}$, and $\mathrm{MeOH}$ ) were mixed with modified M9 medium to form final volumes of $4 \%, 20 \%$, and $40 \%(v / v)$ (as $2 \times$ stocks used for the extracellular protein leakage assay).

\subsection{General Procedure for the Whole-Cell Biocatalytic Conversion of Myricetin into M7GA}

The engineered E. coli strain BPGUT was constructed as described in our previous work [19]. Transformed BPGUT cells were activated in LB medium, and the recombinant proteins were induced to express by the addition of $0.5 \mathrm{mM} \mathrm{IPTG}$, and then incubated for an additional $15 \mathrm{~h}$ at $16{ }^{\circ} \mathrm{C}$. To obtain the whole-cell biocatalyst, the bacterial cells were harvested by centrifugation, and the pellets were washed twice with modified M9 medium to remove the residual medium from the cell pellets. The washed pellets were resuspended in $10 \mathrm{~mL}$ of modified $\mathrm{M} 9$ medium, and the cell density was adjusted to an $\mathrm{OD}_{600}$ of 6 (12 g of cells per liter). Myricetin solid powder or stock solution was added to the above whole-cell biocatalyst system to form a working concentration of $2 \mathrm{mmol} / \mathrm{L}$, which was then kept shaking at $30^{\circ} \mathrm{C}$ for $6 \mathrm{~h}$. The reaction mixture including cells was collected and lyophilized. 
The dried mixture was dissolved in $\mathrm{MeOH}$ and analyzed by HPLC. All of the reactions were carried out in triplicate.

\subsection{Determination of Myricetin and M7GA Solubility}

Myricetin $(0.64 \mathrm{mg})$ or M7GA $(0.99 \mathrm{mg})$ solid powder or stock solution was added to $1 \mathrm{~mL}$ of modified M9 medium and then incubated in a shaker at $30{ }^{\circ} \mathrm{C}$ for $6 \mathrm{~h}$. After centrifugation, the supernatant was analyzed by HPLC to determine the solubility of myricetin or M7GA. All assays were conducted in triplicate.

\subsection{HPLC Analysis}

A $20-\mu \mathrm{L}$ sample of supernatant was used for analysis using a Thermo HPLC system (Thermo Fisher, Germering, Germany) equipped with a GL AQ-C18 reverse-phase column (GL Sciences Inc., Tokyo, Japan, $4.60 \times 250 \mathrm{~mm}, 5 \mu \mathrm{m}$ particle size). The mobile phase was composed of water with $0.05 \%$ TFA (A) and acetonitrile (B) with a gradient program. The analysis of myricetin and M7GA was conducted with a $20-\mathrm{min}$ linear gradient of $20 \%-45 \%$ B. This was followed by isocratic flow with $100 \%$ $\mathrm{B}$ for $5 \mathrm{~min}$ to rinse off hydrophobic compounds and by isocratic development with $20 \% \mathrm{~B}$ for $5 \mathrm{~min}$ to equilibrate the column. The solubility of myricetin $(\mu \mathrm{g} / \mathrm{mL})$ or M7GA $(\mu \mathrm{g} / \mathrm{mL})$ and yields of M7GA $(\mu \mathrm{g} / \mathrm{mL})$ were calculated using the external standard curve method.

\subsection{Flow Cytometry (FCM) Tests}

The whole-cell biocatalyst cells or E. coli wild type cells were incubated in $1 \mathrm{~mL}$ of modified M9 medium containing a certain concentration of liquid organic solvents at $30^{\circ} \mathrm{C}$ for $6 \mathrm{~h}$. After being rinsed and appropriately diluted in $0.85 \%(\mathrm{w} / \mathrm{v}) \mathrm{NaCl}$ solution to reach a final density of $1 \times 10^{7}$ cells $/ \mathrm{mL}$, $600 \mu \mathrm{L}$ of the cell suspension was sampled and stained with $2 \mu \mathrm{L}$ of the premixed dye solution (a 2:1 mixture of SYTO9 and PI stains generated by the LIVE/DEAD BacLight bacterial viability kit) for $15 \mathrm{~min}$ at room temperature in the dark before being subjected to FCM tests using a BD FACS melody flow cytometer (BD Biosciences, Franklin Lakes, NJ, USA). For FCM tests, the sample was excited at $488 \mathrm{~nm}$, and the emission wavelengths were 515-545 nm for the SYTO9 stain and >650 nm for the PI stain, and data were analyzed using FlowJo software (Version 10, BD Biosciences, Franklin Lakes, NJ, USA, 2019).

\subsection{Extracellular Protein Leakage Assay}

The whole-cell biocatalyst was prepared as described above, and the final cell concentration was adjusted to $\mathrm{OD}_{600}=12$. The above cell suspension and different concentrations of organic solvents $(2 \times$ stock) were then separately mixed at a volume ratio of $1: 1$. The mixture was then incubated at $30^{\circ} \mathrm{C}$ for $6 \mathrm{~h}$ followed by a $16,000 \mathrm{~g}$ centrifugation for $20 \mathrm{~min}$. The total content of extracellular proteins leaked from the treated cells in the supernatants was estimated using a protein quantitative kit (Bradford) (Bio-Rad, Hercules, CA, USA). The tests were conducted three separate times.

\subsection{Scale-Up Synthesis of M7GA}

To assess the scale-up whole-cell synthesis of M7GA with low-level organic solvent, two volumes of $20 \mathrm{~mL}$ of DMSO containing $100 \mathrm{mM}$ myricetin were added at $0 \mathrm{~h}$ and $6 \mathrm{~h}$. The scale-up reaction was carried out in a 3-L glass fermenter system (Biotech, Shanghai, China) containing $1 \mathrm{~L}$ of the $12 \mathrm{~g} / \mathrm{L}$ whole-cell catalyst $\left(\mathrm{OD}_{600}=6.0\right)$ at $30{ }^{\circ} \mathrm{C}$ and $350 \mathrm{rpm}$ for $48 \mathrm{~h}$. The $\mathrm{pH}$ was maintained at 6.8-7.0 throughout the process using ammonium hydroxide (28\%) and phosphoric acid (4 M). Dissolved oxygen (DO) was maintained above 50\% during the experiment. Samples were collected at given time points and lyophilized and dissolved in $\mathrm{MeOH}$ for quantification by HPLC. 


\section{Conclusions}

In summary, the effects of five kinds of commonly used water-miscible organic solvents on the transformation of myricetin into M7GA were examined using engineered E. coli BPGUT as a multienzyme whole-cell biocatalyst. Higher M7GA yields were obtained from low-level organic solvents $(2 \%, v / v)$, and in further correlating cell viability and bioconversion yields together with cell membrane integrity, we can conclude that the addition of low-level organic solvents accommodates whole E. coli cells. The fine physical or structural property changes to the cell membrane induced by low-level organic solvent, not the solubility of the substrate or product, were the main causes to improve the yields of the product. However, in spite of the encouraging results of the M7GA yields and cell viability, we have not gained enough information for cell membrane micro-permeabilization induced by low-level organic solvents and their corresponding molecular mechanisms. The application of organic solvents in multistep whole-cell catalysis should be a compromise between two factors: solvent properties and toxic effects. From the results of this research, the former aspect dealing with the solubility of substrates may be neglected. The majority of attention should be paid to the viability and integrity of the cells. Furthermore, whole-cell reactions involve a complex reaction system; other important factors, including the inhibition or denaturation of enzymes, the cellular tolerance to organic solvents, and the density of E. coli cells, may also have effects. Thus, the ways in which low-level organic solvents contribute to the biotransformation of a multienzyme whole-cell biocatalyst must be further investigated. This study highlights the relationships among solubility, cell viability, and performance of the whole-cell catalyst. To further increase stability, the catalytic capability of whole-cell catalysts for modification of other hydrophobic substrates with structure similar to myricetin can be tested.

Supplementary Materials: The following are available online at http://www.mdpi.com/2073-4344/9/11/970/s1. Table S1: the yields of M7GA and the solubilities of myricetin or M7GA obtained in the modified M9 reaction system containing different concentrations of organic solvents; Table S2: the proportion of the live and dead cells as determined by FCM; Table S3: concentrations of proteins released from E. coli BPGUT cells after being exposed to organic solvents for $6 \mathrm{~h}$; Table S4: concentrations of proteins released from E. coli BPGUT cells after being exposed to organic solvents for $12 \mathrm{~h}$; Figure S1: correlations between the M7GA yield and the solubility of myricetin obtained in the modified M9 reaction system containing different concentrations of organic solvents; Figure S2: FCM images of E. coli BPUGT cells or wild type cells after being treated for $6 \mathrm{~h}$ at $30^{\circ} \mathrm{C}$ in a modified M9 solution containing $2 \%(v / v), 5 \%(v / v), 10 \%(v / v)$, and $20 \%(v / v)$ organic solvents, or myricetin $(2 \mathrm{mM})$ and M7GA $(2 \mathrm{mM})$; Figure S3: viability of E. coli BPUGT cells after being treated for $12 \mathrm{~h}$ at $30^{\circ} \mathrm{C}$ in a modified M9 solution containing $2 \%(v / v)$ organic solvents; Figure S4: concentrations of proteins released from E. coli BPGUT cells after the cells were exposed to $2 \%(v / v), 5 \%(v / v), 10 \%(v / v)$ and $20 \%(v / v)$ organic solvents for $12 \mathrm{~h}$; Figure S5: time course for the production of M7GA obtained in a 100-mL shake-flask system containing $10 \mathrm{~mL}$ of whole-cell catalyst.

Author Contributions: Conceptualization, Y.Y. and W.W.; data curation, Y.Y.; formal analysis, Y.Y.; funding acquisition, W.W.; investigation, Y.Y.; methodology, Y.Y., and M.-Z.L.; project administration, W.W.; resources, W.W.; software, Y.Y. and C.-K.L.; validation, Y.Y., and Y.-S.C.; writing-original draft preparation, Y.Y., and M.-Z.L.; writing-review and editing, Y.Y. and W.W.

Funding: This research was funded by the CAMS Innovation Fund for Medical Science (CAMS-2016-I2M-3-012, CAMS-2017-I2M-1-011) and National Mega-project for Innovative Drugs (2018ZX09711001-006-001).

Acknowledgments: We are grateful to Liu Yang (Institute of Materia Medica, Chinese Academy of Medical Sciences) for providing technical assistance.

Conflicts of Interest: The authors declare no conflict of interest.

\section{Abbreviations}

$\begin{array}{ll}\text { DMF } & N, N \text {-dimethylformamide } \\ \text { DMSO } & \text { Dimethyl sulfoxide } \\ \text { EtOH } & \text { Ethanol } \\ \text { FCM } & \text { Flow cytometry } \\ \text { MeOH } & \text { Methanol } \\ \text { M7GA } & \text { Myricetin-7-O-glucuronide } \\ \text { PI } & \text { Propidium iodide }\end{array}$




\section{References}

1. Lin, B.; Tao, Y. Whole-cell biocatalysts by design. Microb. Cell Fact. 2017, 16, 106. [CrossRef] [PubMed]

2. Wu, S.; Li, Z. Whole-cell cascade biotransformations for one-pot multistep organic synthesis. ChemCatChem 2018, 10, 2164-2178. [CrossRef]

3. Ricca, E.; Brucher, B.; Schrittwieser, J.H. Multi-enzymatic cascade reactions: Overview and perspectives. Adv. Synth. Catal. 2011, 353, 2239-2262. [CrossRef]

4. Shi, J.; Wu, Y.; Zhang, S.; Tian, Y.; Yang, D.; Jiang, Z. Bioinspired construction of multi-enzyme catalytic systems. Chem. Soc. Rev. 2018, 47, 4295-4313. [CrossRef] [PubMed]

5. De Carvalho, C.C. Whole cell biocatalysts: Essential workers from nature to the industry. Microb. Biotechnol. 2017, 10, 250-263. [CrossRef] [PubMed]

6. Kadisch, M.; Willrodt, C.; Hillen, M.; Bühler, B.; Schmid, A. Maximizing the stability of metabolic engineering-derived whole-cell biocatalysts. Biotechnol. J. 2017, 12, 1600170. [CrossRef] [PubMed]

7. Wachetmeister, J.; Rother, D. Recent advances in whole cell boicatalsysis. Curr. Opin. Biotech. 2016, 42, 169-177. [CrossRef]

8. Rudroff, F. Whole-cell based synthetic enzyme cascades-light and shadow of a promising technology. Curr. Opin. Chem. Biol. 2019, 49, 84-90. [CrossRef]

9. McAuliffe, J.C. Industrial enzymes and biocatalysis. In Handbook of Industrial Chemistry and Biotechnology; Kent, J.A., Ed.; Springer: Boston, MA, USA, 2012; pp. 1183-1227. ISBN 978-1-4614-4259-2.

10. Krauser, S.; Weyler, C.; Blaß, L.K.; Heinzle, E. Directed multistep biocatalysis using tailored permeabilized cells. Adv. Biochem. Eng. Biotechnol. 2013, 137, 185-234. [CrossRef]

11. Zheng, G.W.; Pan, J.; Yu, H.L.; Ngo-Thi, M.T.; Li, C.X.; Xu, J.H. An efficient bioprocess for enzymatic production of $\mathrm{L}$-menthol with high ratio of substrate to catalyst using whole cells of recombinant $E$. coli. J. Biotechnol. 2010, 150, 108-114. [CrossRef]

12. Li, X.F.; Yuan, T.; Xu, H.; Xin, X.; Zhao, G.; Wu, H.; Xiao, X. Whole-cell catalytic synthesis of puerarin monoesters and analysis of their antioxidant activities. J. Agric. Food Chem. 2019, 67, 299-307. [CrossRef] [PubMed]

13. Gurtovenko, A.A.; Anwar, J. Modulating the structure and properties of cell membranes: The molecular mechanism of action of dimethyl sulfoxide. J. Phys. Chem. B 2007, 111, 10453-10460. [CrossRef] [PubMed]

14. Kim, M.J.; Seo, M.J.; Shin, K.C.; Oh, D.K. Production of 10S-hydroxy-8(E)-octadecenoic acid from oleic acid by whole recombinant Escherichia coli cells expressing 10S-dioxygenase from Nostoc punctiforme PCC 73102 with the aid of a chaperone. Biotechnol. Lett. 2017, 39, 133-139. [CrossRef] [PubMed]

15. Ma, L.; Du, L.; Chen, H.; Sun, Y.; Huang, S.; Zheng, X.; Kim, E.S.; Li, S. Reconstitution of the in vitro activity of the cyclosporine-specific P450 hydroxylase from Sebekia benihana and development of a heterologous whole-cell biotransformation system. Appl. Environ. Microbiol. 2015, 81, 6268-6275. [CrossRef]

16. Cui, J.D.; Jia, S.R.; Sun, A.Y. Influence of amino acids, organic solvents and surfactants for phenylalanine ammonia lyase activity in recombinant Escherichia coli. Lett. Appl. Microbiol. 2008, 46, 631-635. [CrossRef]

17. Janardhan Garikipati, S.V.; Peeples, T.L. Solvent resistance pumps of Pseudomonas putida S12: Applications in 1-naphthol production and biocatalyst engineering. J. Biotechnol. 2015, 210, 91-99. [CrossRef]

18. Honda, K.; Inoue, M.; Ono, T.; Okano, K.; Dekishima, Y.; Kawabata, H. Improvement of operational stability of Ogataea minuta carbonyl reductase for chiral alcohol production. J. Biosci. Bioeng. 2017, 123, 673-678. [CrossRef]

19. Yang, Y.; Wang, H.M.; Tong, Y.F.; Liu, M.Z.; Cheng, K.D.; Wu, S.; Wang, W. Systems metabolic engineering of Escherichia coli to enhance the production of flavonoid glucuronides. RSC Adv. 2016, 6, 33622-33630. [CrossRef]

20. Semwal, D.K.; Semwal, R.B.; Combrinck, S.; Viljoen, A. Myricetin: A dietary molecule with diverse biological activities. Nutrients 2016, 8, 90. [CrossRef]

21. Guo, C.; Zhu, Y.; Weng, Y.; Wang, S.; Guan, Y.; Wei, G.; Yin, Y.; Xi, M.; Wen, A. Therapeutic time window and underlying therapeutic mechanism of breviscapine injection against cerebral ischemia/reperfusion injury in rats. J. Ethnopharmacol. 2014, 151, 660-666. [CrossRef]

22. Ishisaka, A.; Kawabata, K.; Miki, S.; Shiba, Y.; Minekawa, S.; Nishikawa, T.; Mukai, R.; Terao, J.; Kawai, Y. Mitochondrial dysfunction leads to deconjugation of quercetin glucuronides in inflammatory macrophages. PLoS ONE 2013, 8, e80843. [CrossRef] [PubMed] 
23. Spencer, J.P.; Abd-el-Mohsen, M.M.; Rice-Evans, C. Cellular uptake and metabolism of flavonoids and their metabolites: Implications for their bioactivity. Arch. Biochem. Biophys. 2004, 423, 148-161. [CrossRef] [PubMed]

24. Wong, C.C.; Barron, D.; Orfila, C.; Dionisi, F.; Krajcsi, P.; Williamson, G. Interaction of hydroxycinnamic acids and their conjugates with organic anion transporters and ATP-binding cassette transporters. Mol. Nutr. Food Res. 2011, 55, 979-988. [CrossRef] [PubMed]

25. Notman, R.; Noro, M.; O’Malley, B.; Anwar, J. Molecular basis for dimethylsulfoxide (DMSO) action on lipid membranes. J. Am. Chem. Soc. 2006, 128, 13982-13983. [CrossRef] [PubMed]

26. Sandoval, N.R.; Papoutsakis, E.T. Engineering membrane and cell-wall programs for tolerance to toxic chemicals: Beyond solo genes. Curr. Opin. Microbiol. 2016, 33, 56-66. [CrossRef] [PubMed]

27. Marquês, J.T.; Viana, A.S.; De Almeida, R.F. Ethanol effects on binary and ternary supported lipid bilayers with gel/fluid domains and lipid rafts. Biochim. Biophys. Acta 2011, 1808, 405-414. [CrossRef]

28. Weber, F.J.; de Bont, J.A. Adaptation mechanisms of microorganisms to the toxic effects of organic solvents on membranes. Biochim. Biophys. Acta 1996, 1286, 225-245. [CrossRef]

(C) 2019 by the authors. Licensee MDPI, Basel, Switzerland. This article is an open access article distributed under the terms and conditions of the Creative Commons Attribution (CC BY) license (http://creativecommons.org/licenses/by/4.0/). 